\title{
15 Schachtbewehrung
}

Hier ist dargestellt, wie man mit zwei Bewehrungsformen einen Schacht bewehrt.

Betondeckung $\mathrm{c}=3,5 \mathrm{~cm}$. Beton C20/25.

Ist der Schacht etwas tiefer, kommt man auch mit einer Form aus.

Anschluss aus Bodenplatte Anschluss aus Bodenplatte
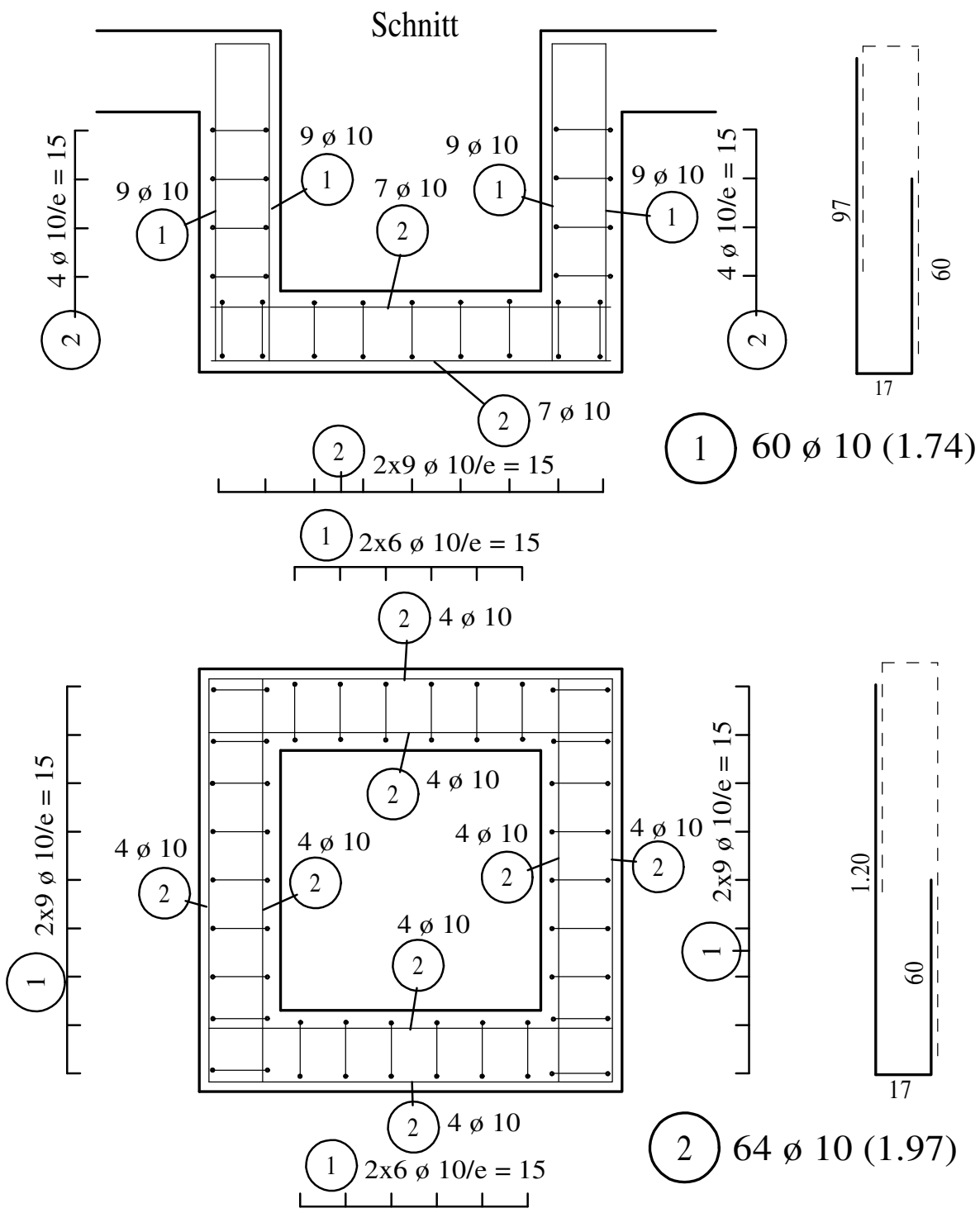

Grundriss 